Original Research Article

\title{
Beneficial effects of crab burrowing on the surface soil properties of newly formed mudflats in the Yellow River Delta
}

\author{
Xuehong Wang ${ }^{\mathrm{a}}$, Yunzhao $\mathrm{Li}^{\mathrm{a}, *}$, Bo Guan ${ }^{\mathrm{b}, *}$, Junbao Yu ${ }^{\mathrm{a}, \mathrm{b}, \mathrm{c}, \mathrm{d}}$, Zhongsheng Zhang ${ }^{\mathrm{c}}$, \\ Haitao $\mathrm{Wu}^{\mathrm{c}}$, Ke Zhang ${ }^{\mathrm{d}}$ \\ a The Institute for Advanced Study of Coastal Ecology, Key Laboratory of Ecological Restoration and Conservation of Coastal Wetlands in \\ Universities of Shandong, Ludong University, No. 186, Hongqi Road, Zhifu District, Yantai, Shandong 264025, PR China \\ ${ }^{\mathrm{b}}$ Key Laboratory of Coastal Environmental Processes and Ecological Remediation, Yantai Institute of Coastal Zone Research, Chinese \\ Academy of Sciences, 17 Chunhui Road, Laishan District, Yantai, Shandong 264003, PR China \\ ${ }^{\mathrm{C}}$ Key Laboratory of Wetland Ecology and Environment, Northeast Institute of Geography and Agricultural Ecology, Chinese Academy of \\ Sciences, 4888 Shengbei Street, Changchun, Jilin 130102, PR China \\ ${ }^{\mathrm{d}}$ College of Tourist and Geoscience, Jilin Normal University, No. 1301, Haifeng Street, Tiexi District, Siping, Jilin 136000, PR China
}

\section{A R T I C L E I N F O}

\section{Article history:}

Received 8 July 2019

Revised 17 November 2019

Accepted 3 December 2019

Available online 10 December 2019

\section{Keywords:}

Crab burrowing

Soil properties

Newly formed mudflat

The Yellow River Delta

\begin{abstract}
A B S T R A C T
Up to now, few studies pay attention on the effects of crab burrowing on soil properties of newly formed mudflats. However, this information is important to protect and manage the new-formed area. Therefore, a field observation was carried out to investigate the effects of crab burrowing on soil properties of newly formed mudflats in the Yellow River Delta. Crab burrow parameters and soil properties were measured at three fixed locations. Results indicated that crab burrowing greatly affected soil texture, but not soil nutrient. Soil textural feature was changed from clay to silt by significantly increasing the proportion of sand $(+3.82 \%)$ and decreasing the proportion of clay $(-4.76 \%)$. Crab burrowing showed significantly negative effects on soil bulk density, $\mathrm{pH}$, soil salinity, and proportion of clay $(p<0.05)$, but significantly positive effects on water content and the proportion of sand and silt $(p<0.05)$. During crab burrowing, soil total carbon, total nitrogen, and $\mathrm{C} / \mathrm{N}$ ratio increased slightly, but there were no significant differences in the properties of soil samples with and without crab burrowing $(p>0.05)$. Overall, crab burrowing had distinct positive effects on surface soil properties, especially the soil texture. These results suggest that crab burrowing would improve surface soil conditions, which in turn would stimulate other life processes and promote the stability of newly formed wetlands.
\end{abstract}

(c) 2019 European Regional Centre for Ecohydrology of the Polish Academy of Sciences. Published by Elsevier B.V. All rights reserved.

\section{Introduction}

Coastal wetlands are considered to be one of the most productive ecosystems in terms of providing habitats for organisms (He et al., 2015; Hopkinson et al., 2019). In the context of wetland degradation and disappear-

\footnotetext{
* Corresponding authors.

E-mail addresses: yzli@yic.ac.cn (Y. Li), bguan@yic.ac.cn (B. Guan).
}

ance, newly formed coastal wetlands in estuaries play an important role in the compensation, maintenance, and the overall health of the global wetland system (Wang et al., 2015). Since crabs are the most abundant and conspicuous macro-invertebrates in coastal wetlands, their high-density burrows are common features of these ecosystems (Nomann and Pennings, 1998). Previous studies paid more attention to the interactions between environmental factors and crabs, with a majority of studies 


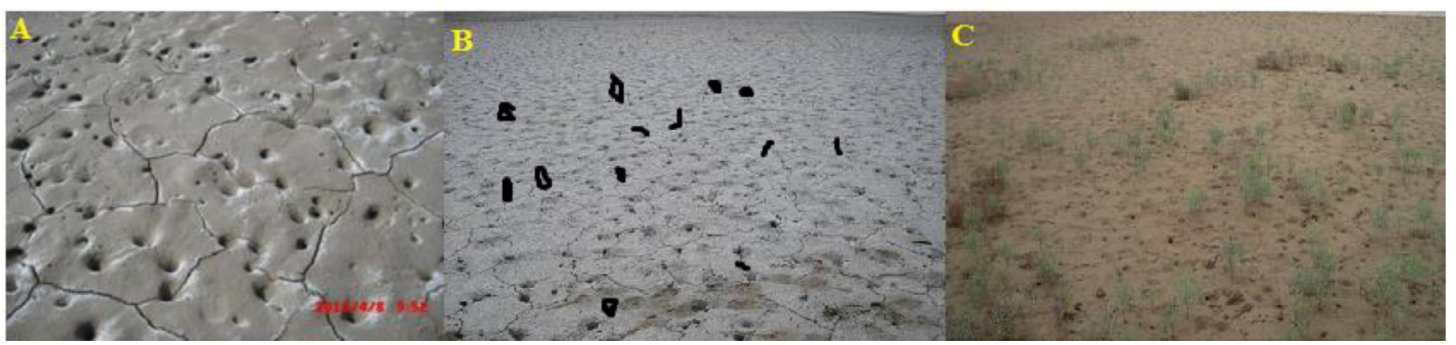

Fig 1. Plant appeared in the mudflat (A: mudflat with crab actions but without plant existing; B: pioneer plant (Suaeda salsa) began to appeared in the mudflat after days of crab actions; C: S. salsa grew well in the mudflat).

focusing on the effects of environmental factors and vegetation on crab activities (Gutiérrez et al., 2006; Koo et al., 2007). However, crabs are commonly considered to be eco-engineers as a function that can be attributed to their burrowing behavior in coastal wetlands (Gutiérrez et al., 2006).

Crab activities significantly impact the surrounding environment. Burrow morphology affects soil properties (Wang, 2008; Webb and Eyre, 2004). Crab burrows can increase the sediment-water-gas interchange and redox potential, accelerate both the addition of $\mathrm{O}_{2}$ into the soil and $\mathrm{CO}_{2}$ emission, and eliminate $\mathrm{H}_{2} \mathrm{~S}$ gas in the soil, thereby reducing the concentrations of soil plant toxins (Gutiérrez et al., 2006; Taylor and Allanson, 1993; Zhao et al., 2016). Crab burrowing can dramatically modify the soil micro-landscape, increase the proportion of coarse particles in the surface soil, and decrease algae coverage (Escapa et al., 2008). Burrowing can increase soil permeability and decrease soil hardness (Chen et al., 2017). Crab burrowing can also increase soil water content, resulte in higher nitrification within burrows and reduce soil salinity (Xin et al., 2009). In addition, crab burrows can passively trap organic matter, which increases the nitrogen content and decreases the $\mathrm{C} / \mathrm{N}$ ratio through ingestion (Boto and Bunt, 1981; Botto et al., 2005; Mchenga and Tsuchiya, 2008). Approximately 68\% of the material ingested by crabs is egested as feces, with little initial nitrogen. Significant nitrogen enrichment occurs after about 2 weeks, associated with a $\mathrm{C} / \mathrm{N}$ ratio of decomposing fecal material that decreases linearly with time (Camilleri, 1984).

Besides, crab activities have remarkable effects on plant distribution and morphology. Mature plants can be influenced directly or indirectly by crabs via several mechanisms (Choy and Booth, 1994). First, crab burrowing changes the physicochemical properties of the soil. Crabs also feed on plant sprouts, which affects their growth and yield directly (Bertness, 1985). Second, during the process of crab foraging and soil modification, the phenotypic plasticity of plants changes gradually. The changes have a significant direct impact on seed biomass and mature seed viability, which directly affect the spread of plants and their capacity to proliferate over long distances (Mckee, 1995). For instance, a series of field and laboratory experiments confirm that crabs are important consumers of mangrove propagules (Dahdouh-guebas et al., 2002; Meziane et al., 2006). The community structures of mangroves are greatly influenced by crab ingestion of seedlings and vegetative forms (Wang et al., 2008). Studies in southern China have indicated that crabs prefer Spartina alterniflora to the common reed and they would rather eat fresh plants than withered ones (Wang, 2008).

The previous studies, however, are mostly carried out in developed coastal wetlands covered by vegetation. In newly formed mudflats, it is difficult to find plants due to the hostile environmental conditions, such as the presence of hard soil, high salinity, and poor soil aeration. However, there are millions of crabs that deposit-feed. After the crabs burrowing for a period of time, pioneer vegetation begins to appear on the mudflats (Fig. 1). Therefore, a hypothesis was put forth positing that crab burrowing improves surface soil properties to the point of being suitable for plant germination and growth. To verify this hypothesis, we conducted a field experiment in newly formed mudflats in the Yellow River Delta (YRD). In our experiment, soil samples with and without crab burrows were collected from this mudflat (1) to examine and compare soil properties in areas with and without crab burrowing; (2) to verify the correlation between changes in soil properties with crab burrowing.

\section{Materials and methods}

\subsection{Study sites}

The study was conducted in the Yellow River Delta Nature Reserve (YRDNR) (Fig. 2) at $37^{\circ} 45^{\prime} 47.91^{\prime \prime}-37^{\circ} 48^{\prime} 19.48^{\prime \prime}$ $\mathrm{N}$ and $119^{\circ} 9^{\prime} 9.83^{\prime \prime}-119^{\circ} 18^{\prime} 48.43^{\prime \prime} \mathrm{E}$ between the Bohai gulf and the Laizhou gulf in eastern China. The climate of the study area is warm temperate continental monsoon, featuring distinct seasons and rainy summers. Detailed averages of regional sunshine hours, temperature, frost-free period, and precipitation are described in the literature (Song et al., 2008). Regional soil descriptions are also found in the literature (He et al., 2007). The main crab species in the new formed mudflats were Helice tridens tientsinensis and Macrophthalmus japonicas (Fig. 3).

\subsection{Data collection}

A newly formed mudflat formed from 1996 was selected for the study area. In this area, 3 transects (T1, T2, and $\mathrm{T} 3$, each with a length of $1000 \mathrm{~m}$ and a width of 


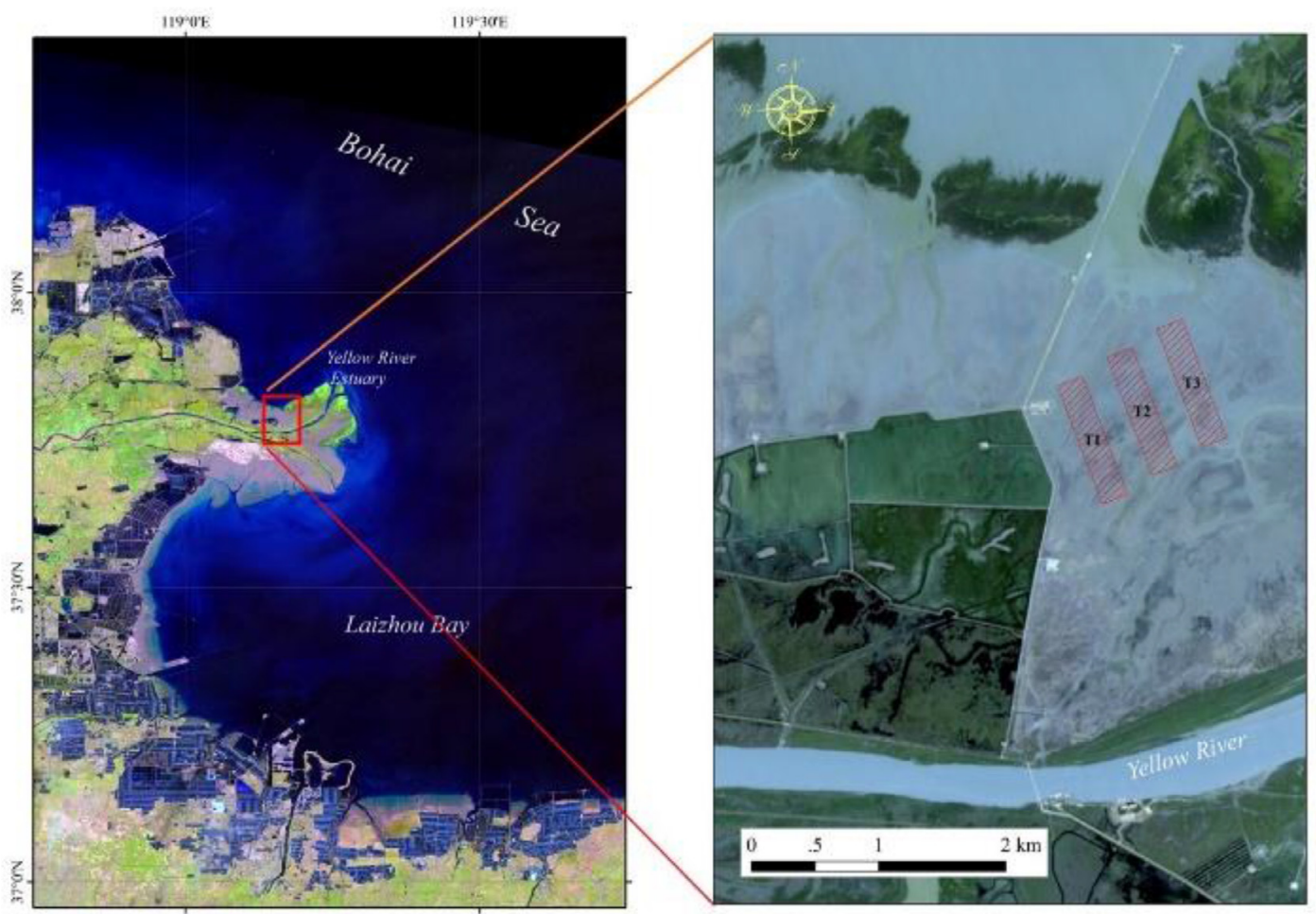

Fig 2. Study area and sampled transects in the YRD.
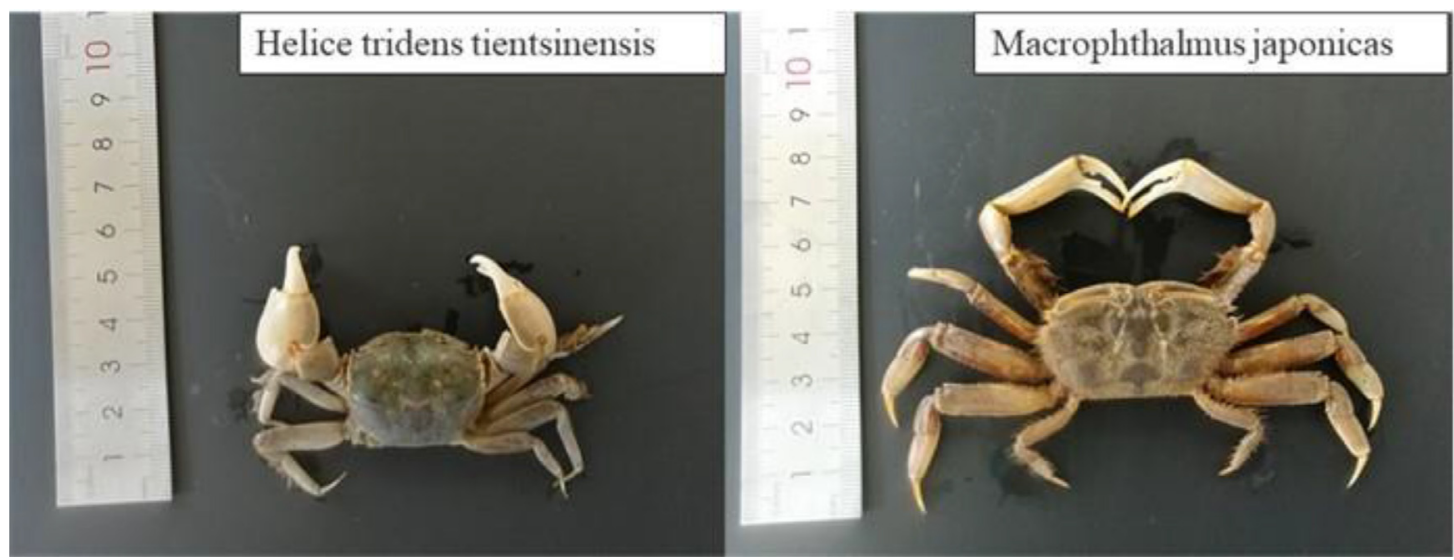

Fig 3. Main crab species in the new formed mudflats (Left is Helice tridens tientsinensis and right is Macrophthalmus japonicas) .

200 m, Fig. 2) were delineated in the study area. In each transect, 5 replicate plots were set in the area with crab burrows and area without crab burrows, respectively. Plot size was $10 \mathrm{~m} \times 10 \mathrm{~m}$ and the distance between sample points was $100 \mathrm{~m}$ from each other. The slope ratio was 1:2000 (site measurement). The intensity of crab activity was represented by spatial burrow density (Taylor and Allanson, 1993). Burrow density, diameter, and height of excavation object were recorded in August, 2016. Burrow density was recorded in situ. Diameter and height of up- ward excavation object was measured by ruler (accuracy is $0.1 \mathrm{~mm}$ ) in situ. In each plot, five random sediment cores from four corners and the center $(0-10 \mathrm{~cm})$ were collected and homogenized to form a composite sample, and soils were collected in the ambient in the area with burrows. At the same time, soils from each plot at depths of 10-60 cm were collected using soil sample barrels and cylinders (Diameter is $100 \mathrm{~mm}$, height is $63.7 \mathrm{~mm}$ ) to examine soil natural heterogeneity in the laboratory. Separate, water content, bulk density (BD), pH, electrical conductivity (EC), 
Table 1

Characteristics of crab burrows.

\begin{tabular}{llll}
\hline & \multicolumn{2}{l}{ Study areas with crab burrowing } \\
\cline { 2 - 4 } & Mean & Minimum & Maximum \\
\hline Density (caves $\left./ \mathrm{m}^{2}\right)$ & $7.74 \pm 3.32$ & 3.00 & 15.00 \\
Opening diameter $(\mathrm{cm})$ & $3.60 \pm 1.00$ & 1.38 & 5.51 \\
Area $\left(\mathrm{cm}^{2}\right)$ & $10.96 \pm 5.66$ & 1.51 & 23.84 \\
Total area $\left(\mathrm{cm}^{2}\right)$ & $83.19 \pm 46.16$ & 8.63 & 181.07 \\
Height of upward excavated object $(\mathrm{cm})$ & $1.43 \pm 0.40$ & 0.55 & 2.19 \\
Total height of upward excavated object $(\mathrm{cm})$ & $11.05 \pm 5.12$ & 3.15 & 20.6 \\
\hline
\end{tabular}

total carbon (TC), and total nitrogen (TN) of surface soil $(0-10 \mathrm{~cm})$ were analyzed to investigate the effects of crab activity on soil properties.

\subsection{Laboratory analysis}

Soil characteristics were examined in the Public Technical Service Center of the Northeast Institute of Geography and Agroecology, Chinese Academy of Sciences.

Water content and bulk density were determined by weighing methods. The diameter, height of cylinders is $100 \mathrm{~mm}$ and $63.7 \mathrm{~mm}$, respectively.

Soil separates were tested using a laser particle size analyzer (Mastersizer 2000, Malvern Company, UK). Gravel (> $2 \mathrm{~mm}$ particle diameter) was screened out from the soil collected, and the composition of soil particles $\leq 2 \mathrm{~mm}$ was measured. A $10 \% \mathrm{H}_{2} \mathrm{O}_{2}$ solution was added to each $0.3 \mathrm{~g}$ soil sample to remove organic matter, and a $10 \% \mathrm{HCl}$ solution was added to remove carbonate salts. Deionized water was added and the liquid supernatant was then removed. Subsequently, the $\mathrm{pH}$ was adjusted to $6.5-7$. The $0.1 \mathrm{ml} / \mathrm{L}$ sodium hexametaphosphate was added, and after ultrasonic vibration for $10 \mathrm{~min}$, the laser particle analyzer was used to measure the percentage volume of soil particles.

The $\mathrm{pH}$ value was determined with an electrode $\mathrm{pH}$ meter (accuracy \pm 0.01 ; Sartorius Basic Meter PB-11, Germany). Before each $\mathrm{pH}$ measurement, the accuracy of the $\mathrm{pH}$ meter was controlled with calibration solutions $(\mathrm{pH}$ 4, 7, and 10; Merck, Darmstadt, Germany). In addition, after each individual measurement, the electrode was cleaned with $\mathrm{AD}$ to avoid contamination of the subsequent fluid. EC values were determined with conductivity meter (DDSJ-319 L, China).

TC and TN in soil were determined by direct combustion with an elemental analyzer (Elementar Vario Macro, Germany). Accurately weigh $25 \mathrm{mg}$ (accurate to $0.001 \mathrm{mg}$ ) soil into a tin foil cup, wrapped the soil tightly and placed it in an auto sampler. The operating conditions of the instrument as follow: the purity of the catalyst in the quartz combustion tube is $99.9 \% \mathrm{WO}_{3}$, the heating temperature is $1120{ }^{\circ} \mathrm{C}$, the oxygenation time is $90 \mathrm{~s}$, the reducing agent in the reduction tube is $99.9 \% \mathrm{Cu}$ wire, the heating temperature is $850{ }^{\circ} \mathrm{C}$, Helium pressure is $0.4 \mathrm{MPa}$ and Oxygen pressure is $0.2 \mathrm{MPa}$. Gas purity: He $\geqslant 99$. 996\% and $\mathrm{O}_{2} \geqslant 99.995 \%$.

\subsection{Data analysis}

According to the "Code of Harbor Hydrology (JTJ2131998)" and "Code of Hydrology for Harbors and Waterways (JTJ213-2015)," which were issued by the Ministry of Communications of China, sediment grains with sizes less than $4 \mu \mathrm{m}$ and greater than $62 \mu \mathrm{m}$ are classified as clay and sand, respectively. Sediment grains with sizes ranging from $4 \mu \mathrm{m}$ to $62 \mu \mathrm{m}$ are classified as silt. Statistical analysis was performed using IBM SPSS 20.0 for Windows. All acquired data were represented by the average of three replicate measurements and standard deviation (S.D.). The differences between soil properties were evaluated using one-way analysis of variance (ANOVA) at the 5\% level.

\section{Results}

\subsection{Crab burrows characteristics}

In newly formed mudflats, characteristics of crab burrow varied significantly $(p<0.001)$. Values of burrow density, diameter, area, and height of upward excavation object all had wide ranges (Table 1 ). Mean burrow density was $7.74 \pm 3.32$ burrow $/ \mathrm{m}^{2}$, ranging from a minimum of 3.00 burrow $/ \mathrm{m}^{2}$ to a maximum of 15.00 burrow $/ \mathrm{m}^{2}$. Opening diameters of the crab burrow varied from $1.38 \mathrm{~cm}$ to $5.51 \mathrm{~cm}$ and burrow areas ranged from $1.51 \mathrm{~cm}^{2}$ to $23.84 \mathrm{~cm}^{2}$. Height of upward excavation object reflected both burrow depth and degree of complexity. The height of upward excavation object could significantly alter the micro-landscape. The mean height of the upward excavation object was $1.43 \pm 0.40 \mathrm{~cm}$, and the total height of the micro-landscape in areas with crab burrows was $11.05 \pm 5.12 \mathrm{~cm}$ higher than the height in areas without crab burrows.

\subsection{Effects of crab burrowing on soil particle size}

Surface soil $(0-10 \mathrm{~cm})$ in the newly formed mudflat without crab burrowing was $16.17 \%$ clay and $6.96 \%$ sand, with the remainder consisting of silt (Table 2). After crab burrowing, the proportion of clay decreased significantly $(-4.46 \%)$, while sand markedly increased $(+3.82 \%)$. Silt showed a slight increase, but this change was negligible $(p>0.05)$. Soil separate at the depth of $10-60 \mathrm{~cm}$ had some differences, but these differences are not significant (Table 2). This demonstrated that the soil natural heterogeneity in the study area is not significant $(p>0.05)$, and crab burrowing greatly affected surface soil separates, es- 
Table 2

Soil separates in different soil horizon at soil with/without crab burrow.

\begin{tabular}{llll}
\hline Soil horizon $(\mathrm{cm})$ & \multicolumn{3}{l}{ Soil separate } \\
\cline { 2 - 4 } & Sand $(>62.000 \mu \mathrm{m})$ & Silt $(4.00 \mu \mathrm{m} \sim 62.00 \mu \mathrm{m})$ & Clay $(<4.000 \mu \mathrm{m})$ \\
\hline SB $(0-10)$ & $10.79 \pm 6.10 \mathrm{~b}$ & $77.50 \pm 2.36 \mathrm{a}$ & $11.71 \pm 5.29 \mathrm{a}$ \\
SNB $(0-10)$ & $6.96 \pm 4.63 \mathrm{a}$ & $76.86 \pm 1.97 \mathrm{a}$ & $16.17 \pm 5.96 \mathrm{~b}$ \\
SB $(10-20)$ & $8.35 \pm 0.72 \mathrm{a}$ & $77.89 \pm 0.67 \mathrm{a}$ & $13.76 \pm 1.38 \mathrm{a}$ \\
SNB $(10-20)$ & $7.99 \pm 0.54 \mathrm{a}$ & $77.91 \pm 0.64 \mathrm{a}$ & $14.10 \pm 1.17 \mathrm{a}$ \\
SB(20-30) & $11.12 \pm 0.62 \mathrm{a}$ & $78.67 \pm 0.61 \mathrm{a}$ & $10.22 \pm 0.88 \mathrm{a}$ \\
SNB(20-30) & $10.67 \pm 0.25 \mathrm{a}$ & $78.27 \pm 0.22 \mathrm{a}$ & $11.06 \pm 0.37 \mathrm{a}$ \\
SB(30-40) & $12.74 \pm 0.11 \mathrm{a}$ & $80.35 \pm 0.10 \mathrm{a}$ & $6.91 \pm 0.02 \mathrm{a}$ \\
SNB $(30-40)$ & $12.81 \pm 0.03 \mathrm{a}$ & $80.31 \pm 0.02 \mathrm{a}$ & $6.88 \pm 0.01 \mathrm{a}$ \\
SB(40-50) & $14.94 \pm 1.48 \mathrm{a}$ & $69.80 \pm 1.74 \mathrm{a}$ & $15.26 \pm 0.81 \mathrm{a}$ \\
SNB(40-50) & $13.67 \pm 0.67 \mathrm{a}$ & $71.72 \pm 0.88 \mathrm{a}$ & $14.61 \pm 0.30 \mathrm{a}$ \\
SB $(50-60)$ & $18.88 \pm 0.14 \mathrm{a}$ & $71.26 \pm 0.14 \mathrm{a}$ & $9.86 \pm 0.01 \mathrm{a}$ \\
SNB(50-60) & $18.48 \pm 0.31 \mathrm{a}$ & $71.62 \pm 0.27 \mathrm{a}$ & $9.91 \pm 0.04 \mathrm{a}$ \\
\hline
\end{tabular}

SB is soil with crab burrow; SNB is soil without crab burrow. "a" and "b" indicate significant differences and non-significant differences at $p<0.05$ level.

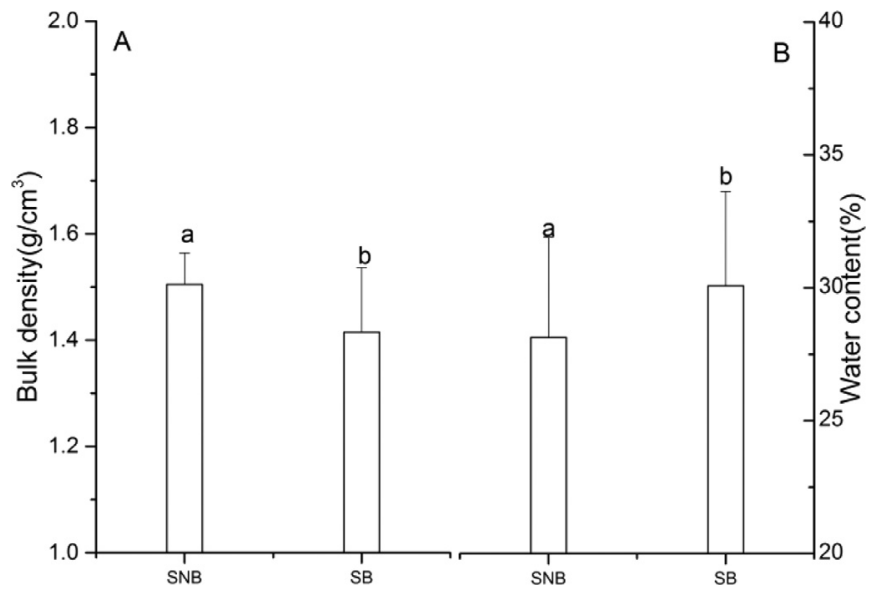

Fig 4. Bulk density (A) and water content (B) in different soils. SNB represents soil without crab burrowing; SB represents soil with crab burrowing.

pecially the proportions of clay and sand. During burrowing, the composition of surface soil separates was changed as the crabs brought coarse particles that had sunk into the lower soil layer back up to the surface and deposited clay particles into the deeper reaches of their burrows.

\subsection{Effects of crab burrowing on the bulk density and water content of soil}

The effects of crab burrowing on the bulk density and water content of soil were significant (Fig. 4). Following crab burrowing, soil bulk density decreased noticeably $(p<0.001)$ while water content increased significantly $(p<0.05)$. This indicated that crab burrowing could loosen soil, which reduced soil hardness allowing soil to hold more water.

\subsection{Effects of crab burrowing on soil $\mathrm{pH}$ and electrical conductivity $(E C)$}

Soil $\mathrm{pH}$ and EC both decreased following crab burrowing (Fig. 5). With the exception of 1 outlier in each case, $\mathrm{pH}$ values ranged from 8.5 to 9.0 and EC values were greater than $3000 \mu \mathrm{s} / \mathrm{cm}$. According to the classification of soil salinization in China, soil in the newly formed mudflat was classified as being slightly saline, although both its $\mathrm{pH}$ and salinity had been significantly reduced.

3.5. Effects of crab burrowing on total carbon (TC) and total nitrogen (TN)

Following crab burrowing, soil TC and TN increased slightly (Fig. 6). However, there were no marked differences between soils with and without crab burrowing (TC: $p=0.231$ and $\mathrm{TN}: p=0.675)$. The $\mathrm{C} / \mathrm{N}$ ratio increased slightly from 36.17 to 36.68 after crab burrowing.

\subsection{Correlation of crab burrow parameters and soil properties}

The correlation between crab burrow characteristics and soil properties indicated that crab burrowing had significantly negative effects on soil bulk density, $\mathrm{pH}$, soil salinity, and the proportion of clay ( $p<0.05$, Table 3$)$. As burrowing increased, soil bulk density, $\mathrm{pH}$, soil salinity, and the proportion of clay decreased markedly. In contrast, crab burrowing showed significantly positive effects on water content and the proportion of sand and silt $(p<$ 

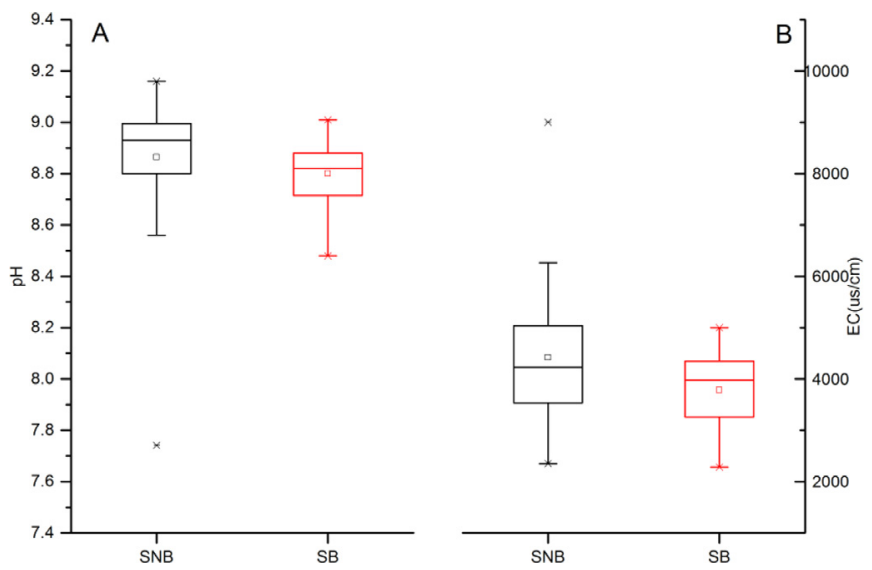

Fig 5. $\mathrm{pH}(\mathrm{A})$ and $\mathrm{EC}(\mathrm{B})$ of different soils. SNB represents soil without crab burrowing; SB represents soil with crab burrowing.

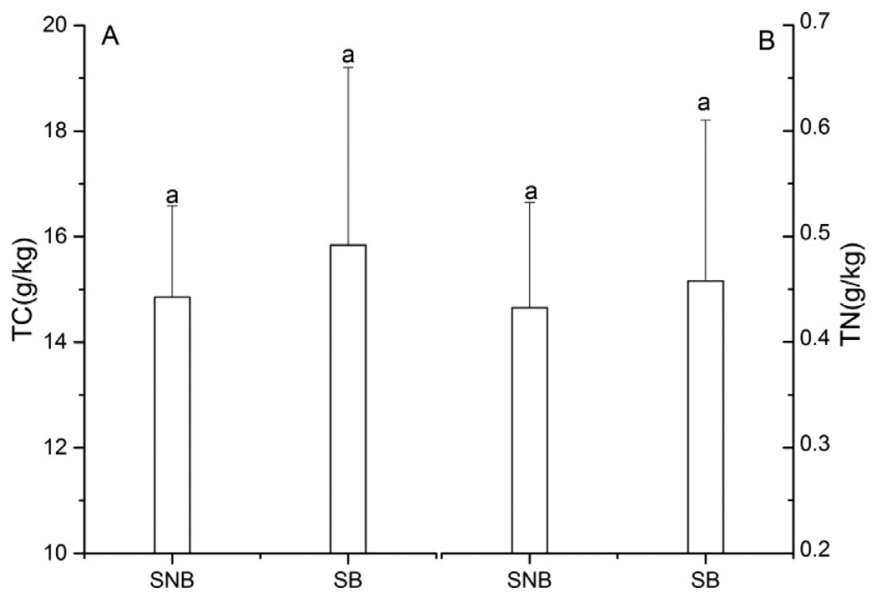

Fig 6. TC (A) and TN (B) in different soils. SNB represents soil without crab burrowing; SB represents soil with crab burrowing.

Table 3

Correlation between soil properties and crab burrow characteristics.

\begin{tabular}{|c|c|c|c|c|c|c|c|c|c|c|}
\hline & BD & WC & $\mathrm{pH}$ & $\mathrm{EC}$ & TC & TN & $\mathrm{C} / \mathrm{N}$ & LG & MG & SG \\
\hline Burrow density & $-0.531^{* *}$ & $0.287^{* *}$ & $-0.264^{* *}$ & $-0.298^{* *}$ & -0.003 & -0.008 & 0.081 & $0.400^{* *}$ & $0.247^{* *}$ & $-0.434^{* *}$ \\
\hline Burrow diameter & $-0.580^{* *}$ & $0.316^{* *}$ & $-0.311^{* *}$ & $-0.265^{* *}$ & 0.037 & 0.089 & -0.042 & $-0362 * *$ & $0.235^{* *}$ & $-0.388^{* *}$ \\
\hline Burrow area & $-0.580^{* *}$ & $0.316^{* *}$ & $-0.311^{* *}$ & $-0.265^{* *}$ & 0.037 & 0.089 & -0.042 & $-0362 * *$ & $0.235^{* *}$ & $-0.388^{* *}$ \\
\hline Burrow total area & $-0.576^{* *}$ & $0.326^{* *}$ & $-0.298 * *$ & $-0.284 * *$ & 0.023 & 0.045 & 0.012 & $0.372^{* *}$ & $0.265^{* *}$ & $-0.417^{* *}$ \\
\hline Height of excavated object & $-0.580^{* *}$ & $0.316^{* *}$ & $-0.311^{* *}$ & $-0.265^{* *}$ & 0.037 & 0.089 & -0.042 & $-0362^{* *}$ & $0.235^{* *}$ & $-0.388^{* *}$ \\
\hline Height of excavated object & $-0.549 * *$ & $0.311^{* *}$ & $-0.300^{* *}$ & $-0.290^{* *}$ & 0.004 & 0.028 & 0.032 & $0.396^{* *}$ & $0.248^{*}$ & $-0.438^{* *}$ \\
\hline
\end{tabular}

BD: Bulk density, WC: Water content, EC: Salinity, TC: Total carbon, TN: Total nitrogen, LG: Proportion of soil grade $>62 \mu \mathrm{m}$, MG: Proportion of soil grade that is $4-62 \mu \mathrm{m}$, SG: Proportion of soil grade $<4 \mu \mathrm{m}$.

Note: ${ }^{* *}$ indicates extremely significant correlation at $p<0.01$ level

0.05). As the number of burrows increased, water content and the proportion of sand and silt increased noticeably. However, crab burrowing did not show significantly effects on nutrient cycles.

\section{Discussion}

Crabs are the most important species in the macrobenthos, both in temperate salt marshes and in trop- ical mangroves (Kristensen, 2008; Lee, 1998; Yan and Tong, 2017). They usually exist in high densities within the intertidal zone (Koo et al., 2007). Crabs are generally regarded as the ecosystem engineers of tidal wetlands. An overwhelming majority of crabs in tidal flats burrow and maintain burrow structures to avoid predators, perform important life activities and harsh environmental conditions (in the form of high temperatures and water loss) (Onda and Itakura, 1997; Takahashi et al., 2001). The ecosystem engineering effect of crabs can thus be majorly 
attributed to their burrowing behavior (Bortolus and Iribarne, 1999; Fanjul et al., 2007).

Crab burrowing and crab burrows can enhance surface area and the complexity of micro topography (Warren and Underwood, 1986). Wolfrath (1992) reported that surface area increased $30 \%-70 \%$ as a result of crab burrowing. In the present study, burrow area and height of upward excavation object were as much as $181.07 \mathrm{~cm}^{2}$ and $20.6 \mathrm{~cm}$, respectively. Consequently, the soil surface area increased markedly and the micro-landscape was changed significantly, providing favorable conditions for other life processes.

Crab burrowing also has profound effects on soil properties (Botto et al., 2005). The process of burrowing can lead to an increase in soil permeability and a decrease in soil hardness. The water content in regions with burrowing was found to be higher than that in regions with no burrowing (Xin et al., 2009). Our results are in accordance with those of the previous studies. In our study, crab burrowing reduced soil bulk density (up to 6\%) and soil salinity (by $780.32 \mu \mathrm{s} / \mathrm{cm}$ ), and increased water content (1.95\%).

Crab burrowing influenced the soil nutrient by promoting the exchange of water and gas (Botto et al., 2006; Botto et al., 2005; Zhao et al., 2016). The increase of soil surface area improves the redox reaction and the transport of dissolved matter, which can further affect biogeochemical processes (Webb and Eyre, 2004). Greater soil surface area also significantly increases soil oxidation and changes the nutrient distribution both inside and outside crab burrows (Fanjul et al., 2007), and provides the necessary reaction substrate for soil nitrification (Lee, 1990). The oxidation potential of burrow walls can be improved dramatically with a sufficient supply of oxygen, which correspondingly increases the soil nitrifying potential. As a result, excess nitrogen within the soil increases, which reduces the availability of inorganic nitrogen in the deeper burrows. This noticeably increases soil $\mathrm{N}$ content and, as a consequence, reduces the $\mathrm{C} / \mathrm{N}$ ratio (Wang, 2008). Our results about $\mathrm{C}$ and $\mathrm{N}$ is different with previous studies. In our study, crab burrowing and burrows did affect the content of TC and TN, although this effect was not statistically significant $(p>0.05)$. We found that the $\mathrm{C} / \mathrm{N}$ ratio increased slightly in the crab burrow area, indicating a positive effect of crab burrowing on soil $\mathrm{C} / \mathrm{N}$. There may be three possible explanations for these inconsistent results. One is that the climate condition in our study differed from other investigations. Our study was carried out in salt marsh located of a warm temperate zone, while other studies took place in mangrove ecosystems of tropical and subtropical zones. Different hydrothermal conditions might impact the transformation of nutrients responding to crab activities (Lee, 1998). A second explanation is differences of vegetation coverage. Our study area was a mudflat with no plant coverage, while other study areas were covered by various plants. The existence of plants has been shown to have a great effect on the crab behavior, likely resulting in different elements cycles (Wang et al., 2008). A third reason was the differences of crab feeding patterns (Taylor and Allanson, 1993). Crabs deposit-feed in mudflats without vegetation, while they leaf-feed in areas with vegetation (Camilleri, 1989). The consumption of leaf litter by crabs reduces tidal transformation and affects the accumulation of organic matter (Emmerson and Mcgwynne, 1992). The results suggest that differences in climate, plant coverage, and crab feeding patterns may be attributed to response of nutrient cycles to crab behavior.

\section{Conclusions}

In the newly formed mudflats, crab burrowing significantly improved the micro-landscape and soil texture. Crab burrowing also reduced soil hardness, $\mathrm{pH}$, and soil salinity, and increased soil water content correspondingly. However, crab burrowing did not show significant effects on TC and $\mathrm{TN}$ and $\mathrm{C} / \mathrm{N}$ ratio. To summarize, in the newly formed YRD mudflat, crab burrowing played a crucial role in the improvement of surface soil conditions, and then provide suitable environments for the germination and growth of pioneer plant, which are important in fostering the stability of newly developed ecosystems, as well as protecting and restoring wetlands.

\section{Declaration of Competing Interest}

The authors declare that we do not have any commercial or associative interest that represents a conflict of interest in connection with the work submitted.

\section{Ethical statement}

Authors state that the research was conducted according to ethical standards.

\section{Author contributions}

Xuehong Wang, YunZhao Li and Junbao Yu designed the research. Xuehong Wang, Bo Guan, Zhongsheng Zhang, Haitao $\mathrm{Wu}$ performed the experiment. YunZhao Li analyzed and interpreted the data. Xuehong Wang wrote the paper, Ke Zhang identified the crab species and took photos. All authors read and approved the final manuscript.

\section{Acknowledgments}

This work was supported by the National Key R and D Program of China (2017YFC0505901 and 2017YFC0505902) and the National Natural Science Foundation of China (41301052 and 41871091). We would like to thank LetPub (www.letpub.com) for providing linguistic assistance during the preparation of this manuscript.

\section{Funding body}

None.

\section{References}

Bertness, M.D., 1985. Fiddler crab regulation of Spartina alterniflora production on a New England salt marsh. Ecology 66 (3), 1042-1055.

Bortolus, A., Iribarne, O.O., 1999. Effects of the SW Atlantic burrowing crab Chasmagnathus granulata on a Spartina salt marsh. Marine Ecol. Progr. 178 (3), 79-88. 
Boto, K.G., Bunt, J.S., 1981. Tidal export of particulate organic matter from a Northern Australian mangrove system. Estuarine Coast. Shelf Sci. 13 (3), 247-255.

Botto, F., et al., 2006. Ecological importance of passive deposition of organic matter into burrows of the SW Atlantic crab Chasmagnathus granulatus. Marine Ecol. Progr. 312 (8), 201-210.

Botto, F., Valiela, I., Iribarne, O., Martinetto, P., Alberti, J., 2005. Impact of burrowing crabs on $\mathrm{C}$ and $\mathrm{N}$ sources, control, and transformations in sediments and food webs of SW Atlantic estuaries. Marine Ecol. Progr. 293 (1), 155-164.

Camilleri, J., 1989. Leaf choice by crustaceans in a mangrove forest in Queensland. Marine Biol. 102 (4), 453-459.

Camilleri, J.C., 1984. Litter decomposition and resource partitioning in a mangrove forest: a case study in systems ecology and modelling. Sci. News 165 (15), 227 -227.

Chen, T.Y., Hwang, G.W., Mayfield, A.B., Chen, C.P., Lin, H.J., 2017. The relationship between intertidal soil composition and fiddler crab burrow depth. Ecol. Eng. 100, 256-260.

Choy, S.C., Booth, W.E., 1994. Prolonged inundation and ecological changes in an Avicennia mangrove: implications for conservation and management. Hydrobiologia 285 (1-3), 237-247.

Dahdouh-guebas, F., Kairo, J.G., Jayatissa, L.P., Cannicci, S., Koedam, N., 2002. An ordination study to view vegetation structure dynamics in disturbed and undisturbed mangrove forests in Kenya and Sri Lanka. Plant Ecol. 161 (1), 123-135.

Emmerson, W.D., Mcgwynne, L.E., 1992. Feeding and assimilation of mangrove leaves by the crab Sesarma meinerti de Man in relation to leaf-litter production in Mgazana, a warm-temperate southern African mangrove swamp. J. Exp. Marine Biol. Ecol. 157 (1), 41-53.

Escapa, M., Perillo, G.M.E., Iribarne, O., 2008. Sediment dynamics modulated by burrowing crab activities in contrasting SW Atlantic intertidal habitats. Estuarine Coast. Shelf Sci. 80 (3), 365-373.

Fanjul, E., Grela, M.A., Iribarne, O., 2007. Effects of the dominant SW atlantic intertidal burrowing crab chasmagnathus granulatus on sediment chemistry and nutrient distribution. Marine Ecol. Progr. 341 (12), 177-190.

Gutiérrez, J.L., et al., 2006. The contribution of crab burrow excavation to carbon availability in surficial salt-marsh sediments. Ecosystems 9 (4), 647-658.

He, Q., Altieri, A.H., Cui, B., 2015. Herbivory drives zonation of stress-tolerant marsh plants. Ecology 96 (5), 1318-1328.

He, Q., et al., 2007. Vegetation distribution patterns to the gradients of water depth and soil salinity in wetlands of Yellow River delta, china. Wetland Sci. 5 (3), 208-214

Hopkinson, C.S., Wolanski, E., Cahoon, D.R., Perillo, G.M.E., Brinson, M.M., 2019. Chapter 1 - Coastal Wetlands: A Synthesis. In: Perillo, G.M.E., Wolanski, E., Cahoon, D.R., Hopkinson, C.S. (Eds.), Coastal Wetlands. Elsevier, pp. 1-75.

Koo, B.J., Kwon, K.K., Hyun, J.H., 2007. Effect of environmental conditions on variation in the sediment-water interface created by complex macrofaunal burrows on a tidal flat. J. Sea Res. 58 (4), 302-312.

Kristensen, E., 2008. Mangrove crabs as ecosystem engineers; with emphasis on sediment processes. J. Sea Res. 59 (1), 30-43.

Lee, S.Y., 1990. Primary productivity and particulate organic matter flow in an estuarine mangrove-wetland in Hong Kong. Marine Biol. 106 (3), 453-463.
Lee, S.Y., 1998. Ecological role of grapsid crabs in mangrove ecosystems: a review. Mari Fresh Res. Marine Freshw. Res. 49 (4), 335-343.

Mchenga, I.S.S., Tsuchiya, M., 2008. Nutrient dynamics in mangrove crab burrow sediments subjected to anthropogenic input. J. Sea Res. 59 (1), 103-113.

Mckee, K.L., 1995. Mangrove species distribution and propagule predation in Belize: an exception to the dominance-predation hypothesis. Biotropica 27 (3), 334-345.

Meziane, T., D’Agata, F., Lee, S.Y., 2006. Fate of mangrove organic matter along a subtropical estuary: small-scale exportation and contribution to the food of crab communities. Marine Ecol. Progr. 312 (8), 15-27.

Nomann, B.E., Pennings, S.C., 1998. Fiddler crab-vegetation interactions in hypersaline habitats. J. Exp. Marine Biol. Ecol. 225 (1), 53-68.

Onda, Y., Itakura, N., 1997. An experimental study on the burrowing activity of river crabs on subsurface water movement and piping erosion. Geomorphology 20 (3-4), 279-288.

Song, C., Liu, G., Liu, Q., Cao, M., Huang, C., 2008. Distribution patterns of plant communities in the Yellow River Delta and related affecting factors. Chin. J. Ecol. 27 (12), 2042-2048.

Takahashi, M., Suzuki, N., Koga, T., 2001. Burrow defense behaviors in a sand-bubbler crab, Scopimera globosa, in relation to body size and prior residence. J. Ethol. 19 (2), 93-96.

Taylor, D.I., Allanson, B.R., 1993. Impacts of dense crab populations on carbon exchanges across the surface of a salt marsh. Marine Ecol. Progr. 101 (1-2), 119-129.

Wang, J., 2008. The Dynamics of Plant Community Distribution of the Salt Marshes in the Yangtze River Estuary as Influenced by Spartina Alterniflora Invasions. Fudan University.

Wang, J.Q., et al., 2008. Exotic Spartina alterniflora provides compatible habitats for native estuarine crab Sesarma dehaani in the Yangtze River estuary. Ecol. Eng. 34 (1), 57-64.

Wang, X., Li, Y., Dong, H., Tong, S., 2015. Vegetation patterns in a new-born coastal wetland in the Yellow River Delta, China. Fresenius Environ. Bull. 24 (12A), 4465-4471.

Warren, J.H., Underwood, A.J., 1986. Effects of burrowing crabs on the topography of mangrove swamps in New South Wales. J. Exp. Marine Biol. Ecol. 102 (2), 223-235

Webb, A.P., Eyre, B.D., 2004. The effect of natural populations of the burrowing and grazing soldier crab (Mictyris longicarpus) on sediment irrigation, benthic metabolism and nitrogen fluxes. J. Exp. Marine Biol. Ecol. 309 (1), 1-19.

Wolfrath, B., 1992. Burrowing of the fiddler crab Uca tangeri in the Ria Formosa in Portugal and its influence on sediment structure. Marine Ecol. Progr. 85 (3), 237-243.

Xin, P., Jin, G., Li, L., Barry, D.A., 2009. Effects of crab burrows on pore water flows in salt marshes. Adv. Water Resour. 32 (3), 439-449.

Yan, W., Tong, C., 2017. Distribution characteristics of crab burrows in Phragmites australis and Spartina alterniflora salt marshes in the Yangtze Estuary and their influencing factors. Acta Ecologica Sinica 37 (16), 5504-5513.

Zhao, H., et al., 2016. Effects of tidewater and crab burrowing on $\mathrm{H}_{2} \mathrm{~S}$ emission and Sulfur storage in Spartina alterniflora marsh. CLEAN Soil Air Water 43 (12), 1682-1688. 